\title{
Analysis of the Implementation of Patient Guidance of Fall Risk at X Hospital
}

\section{AT Titis Ayu Wulandari*}

*Correspondent Author: ayuthysha@gmail.com

*Master of Hospital Management, Unversitas Muhammadiyah Yogyakarta, Indonesia

\begin{tabular}{l}
\hline I N D E X I N G \\
\hline Keywords: \\
Implementation; \\
Patient Safety; \\
Risk Fall;
\end{tabular}

\begin{abstract}
A B S T R A C T
The objectives of this study are to find out the knowledge concerning the guidelines fall risk to the patients, to find out the ability of the nurses in the simulation of the guiding steps for the risk for falls, to find out the conformity of the review on the medical records of the patients, and to find out the obstacles in preventing risk for falls. It is a mix method study, which is a quantitative method with cross-sectional approach, and qualitative method with descriptive research design. The population of this study were 37 respondents for the quantitative research and 9 informants for the qualitative research. The results of the questionnaire indicate the presence of knowledge that most have fair criteria that is as much as $46 \%$. The results of the medical record study show most of the full or compliant as much as $89.2 \%$. While the structured interview showed different results. The conclusions of this study were that there was sufficient knowledge but lacked of discipline in completing the medical records, and there were still some obstacles in implementing the guidelines for risk for falls.
\end{abstract}

Kata Kunci:

Implementasi;

Keselamatan Pasien ;

Risiko Jatuh;

\begin{abstract}
Tujuan penelitian ini dilakukan untuk mengetahui pengetahuan perawat tentang panduan resiko jatuh, mengetahui kemampuan perawat dalam simulasi langkah-langkah panduan risiko jatuh, mengetahui kepatuhan telaah rekam medis pasien, mengetahui hambatan dalam pencegahan risiko jatuh. Penelitian ini merupakan penelitian mix method, yaitu metode kuantitatif dengan pendekatan cross sectional dan metode kualitatif dengan rancangan penelitian deskriptif. Populasi penelitian ini berjumlah 37 responden untuk penelitian kuantitatif. Sedangkan penelitian kualitatif berjumlah 9 Informan. Hasil kuesioner menunjukkan bahwa pengetahuan perawat sebagian besar memiliki kriteria cukup yaitu sebanyak $46 \%$. Hasil telaah rekam medis menunjukkan sebagian besar terisi lengkap atau patuh yaitu sebanyak $89,2 \%$. Sedangkan hasil wawancara terstruktur menunjukkan hasil yang berbeda-beda. Kesimpulan dari penelitian ini terdapat pengetahuan yang cukup, namun kurang disiplin dalam pengisian rekam medis, dan masih terdapat hambatan-hambatan dalam pelaksanaan panduan risiko jatuh.
\end{abstract}

(C) 2017 JMMR. All rights reserved

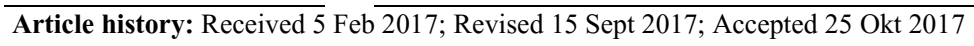

\section{INTRODUCTION}

Hospital is a health care institution that provide complete personal health services that provide inpatient, outpatient and emergency care services ${ }^{1}$. The patient safety of the hospital is a system where the hospital make safer patient care which includes risk assessment, patient risk identification and management, incident reporting and analysis, learning from incidents and follow-up skills as well as the implementation of solutions to minimize risks and prevent injuries caused by errors resulted from any improper action or fail to take an appropriate action ${ }^{2}$.

Patient safety consists of 6 objective, they are: (1) identifying the patient correctly, (2) improving effective communication, (3) preventing drug administration errors, (4) preventing procedural, site and patient errors in surgery, (5) preventing the risk of infection and, (6) preventing the risk of fall-related injuries. The sixth objective set by JCI shows that there should be a commitment from the hospital to reduce the risk of fall-related injuries to the patients during providing services in the hospital ${ }^{3}$.

The Minimum Standards of Hospital Services state that it is $100 \%$ expected that the incidence of falling patients which resulted in disability or death do not occur in hospital ${ }^{4}$. The incidence of falling patients is included into the top three hospital medical incidents and ranked second after medicine error ${ }^{5}$. From the report, it was obtained that there were 34 falling incidents. It proves that the patient-fall incident is still high in Indonesia ${ }^{6}$.

In 2013, at Private Hospital Yogyakarta, it was reported the patient safety related incident, especially for the falling incident, had a frequency of 3 patients, whereas in 2014, it was reported that the falling incident had a 
frequency of 4 patients $^{7}$. The objectives of this study are to find out the knowledge concerning the guidelines for risk for falls to the patients, to find out the ability of the nurses in the simulation of the guiding steps for the risk for falls, to find out the conformity of the review on the medical records of the patients, and to find out the obstacles in preventing risk for falls.

\section{RESEARCH METHOD}

It is a mix method study, which is a quantitative method with cross-sectional approach, and qualitative method with descriptive research design. The population of this study were 37 respondents for the quantitative research and 9 informants for the qualitative research.

\section{RESULT AND DISCUSSION}

This quantitative research respondent is a nurse of inpatient room which amounts to 37 people which is located in Private Hospital in Yogyakarta. While this qualitative research informant is hospital director, nursing manager, nursing assistant assistant, and room supervisor who numbered 9 people work in PKU Muhammadiyah Gamping Hospital. Data analysis using Descriptive Analysis method. At this stage, the questionnaires concerning the guidelines for risk for falls were distributed in order to find out to what extent the knowledge of the nurses who served in the inpatient ward on the risk for falls to the patients.

\section{RESULT AND DISCUSSION}

The results showed that there were $35 \%$ of 37 respondents had a good knowledge. While there were $46 \%$ of 37 respondents had a fair knowledge and $19 \%$ of 37 respondents had a poor knowledge. The description is presented in table 1 And the researcher provided a checklist of the completion of medical records on initial assessment and re-assessment of risk for falls to the patients, as well as the completion on patient monitoring sheets. From the results of the research, it was found that there were not all medical records review compliant in completing the medical record. In January 18,2017 , there were $89,2 \%$ of 83 medical records completed or compliant and $10,8 \%$ of 83 medical records incompleted (non-compliant). The description is presented in table 2 .
Table 1. Precentage of knowledge about the implementation of fall risk guidelines inpatient nurses.

\begin{tabular}{lcccc}
\hline Ward Name & Good & Fair & Poor & Amount \\
\hline Firdaus & $75 \%$ & $25 \%$ & $0 \%$ & $100 \%$ \\
Naim & $60 \%$ & $40 \%$ & $0 \%$ & $100 \%$ \\
Wardah & $50 \%$ & $50 \%$ & $0 \%$ & $100 \%$ \\
Zaitun & $20 \%$ & $60 \%$ & $20 \%$ & $100 \%$ \\
AR Royan & $30 \%$ & $20 \%$ & $50 \%$ & $100 \%$ \\
AL Kautsar & $0 \%$ & $85,7 \%$ & $15,3 \%$ & $100 \%$ \\
\hline
\end{tabular}

Tabel 2. Precentage of medical record reviewed in Hospital Ward.

\begin{tabular}{lcc}
\hline \multicolumn{1}{c}{ Ward Name } & Compliant & $\begin{array}{c}\text { Non- } \\
\text { Compliant }\end{array}$ \\
\hline Firdaus & 100 & $0 \%$ \\
Naim & 100 & $0 \%$ \\
Wardah & 100 & $0 \%$ \\
Zaitun & 90,9 & $9,1 \%$ \\
AR Royan & 62,5 & $37,5 \%$ \\
AL Kautsar & 88,2 & $11,8 \%$ \\
\hline
\end{tabular}

Obstacles in the implementation of the guidelines of risk for falls to the patientsat PKU Muhammadiyah Hospital of Gamping based on axial coding

The answer to the question of definition of fall risk is quite striking. Three out of nine informants are for patients. One of the nine informants who responded by translating was the cause of the cause of the patient's fall. Two of the nine informants answered were thedefinition of risk of falling into the attention and the unkempt environment. Three of the nine informants translated were potential for falling and supported by a declining patient condition.

It was shown that there were some significant differences on the answers provided by the informants to the question on the cause of patient fall. One of nine informants answered that the high risk to cause the patient fall. Two of nine informants answered that the declining condition of the patient to cause the patient fall. Two of nine informants answered that the absence of follow-up and incomplete assessment to cause the patient fall which makes unable to monitor the condition of the patients. Three of nine informants answered that there are many factors to cause the patient fall. One of nine informants answered that the lack of education given to both the patients and their family to cause the patient fall.

It was shown that there were some differences on the answers provided by the informants to the question on the patient fall preventive solution. Seven of nine informants answered that conducting initial assessment and reassessment were the solutions for preventing the patient 
fall. One of nine informants answered that the anticipation of medicines, equipment and the environment for the inpatients as the patient fall preventive solution. One of nine informants answered that the use of side rail and surveillance to the patient are appropriate for the inpatients.

It was shown that there were some differences on the answers provided by the informants to the question on the obstacles in preventing the risk for falls for the patients. Five of nine informants answered that there is a lack of compliance of the patients and family cooperation in assisting patient surveillance are the obstacles for nurses to prevent the patient fall. One of nine informants answered that anxious patients or clouding of consciousness are the obstacles. Two of nine informants answered that the obstacle is the non-compliance in completing the assessment sheets so that makes difficult to monitor the patients' condition. One of nine informants answered that the obstacle is the lack of knowledge of the nurses and the family.

It was shown that there were some differences on the answers provided by the informants to the question of the risk management system for patient fall. Seven of nine informants answered that it is on the reporting of incidents in case of an incident occured. One of nine informants answered that it is on the training for hospital employees and staffs and the provision of assessment sheets regarding the risk for falls. One of nine informants answered that it is on the risk for falls prevention according to the SOP of the hospital.

It was shown that there were some differences on the answers provided by the informants to the question on how to monitor the risk for falls for the patients. Six of nine informants answered that it is the reassessment to monitor the patients. Three of nine informants answered that it depends on the condition of the patients, observing their condition, and completing the scale forms for patient fall.

It was shown that the answers to the question on the differences in the risk for falls monitoring for children, adults and geriatric patients were similar as all informants answered that it is the use of morse fall scale for adults, humpty dumpty for children and sidney score for geriatric patients.

It was shown that the answers to the question on warning given to the nurses who are on duty were similar as all informants answered nothing. However, the on-duty nurses shall make incident report, conduct investigative analysis, audits, and evaluation from the beginning until an incident occurs.

\section{DISCUSSION}

\section{The level of nurse's knowledge on the risk for falls}

The level of knowledge is divided into 3 categories: 1). Good, if the answers provided by the respondents have a score $>75 \%$ of the highest score. 2). Fair, if the answers provided by the respondents have a score of between 40$75 \%$ of the highest value. 3 ). Poor, if the answers provided by the respondents have a score $<40 \%$ of the highest score.

Thus, the results of this study indicated that there is a lack of knowledge and comprehension of nurses on the risk for falls guidelines ${ }^{8}$.

The degree of nurse compliance in the patient's medical record review during the study regarding the assessment of risk for falls for the patients.

There were many reports of patient safety incidents sent by the hospitals uncompleted. Based on these reports, the root of the problem is still mostly addressed to the employee factor rather than on the system ${ }^{9}$.

Obstacles in the implementation of the guidelines of risk for falls to the patientsat PKU Muhammadiyah Hospital of Gamping.

Fall risk is a nursing diagnosis according to the North American Nursing Diagnosis Association (NANDA) which is an increase in dexterity to a decrease that can ucause physical damage ${ }^{10}$. In a study conducted by Aristo in 2007, found there were $55.5 \%$ of patients who had experienced a decrease in incidents dropped with increasing age. While the disturbance of balance and difficulty walking is ranked second because of the causes of the factors down. In addition, there are posture changes, gait, postural swing, sensory system, and functional mobility. Older age is associated with reduced propioceptive, degenerative processes in the vestibular system, slower reflexes and weakening of muscle strength which is essential in maintaining posture. Balance can also be disrupted by illness and drugs.

All of these changes can contribute to falling, especially for the ability to prevent falling when having slipped or facing a dangerous environmental situation ${ }^{11}$. In preventing the patient from falling, the followings can be conducted: a). always leaving the bed with the lowest horizontal position (for adjustable bed). b). Putting up the bed rail and checking the safety. c). Checking and adjusting the primary objects such as the wheels of the bed. d). Cleaning and removing tools that is not necessary for any 
longer. e). Giving advise for the use of handles along the corridor wall while walking. f). Observing patients well with any sign of weakness or unstable gait. g). Ensuring for sufficient light (no lights are turned off), especially for dusk and night ${ }^{12}$. There are several cultures within the hospital organization that can inhibit the implementation of patient safety program, such as the fear of the law, how to view errors/KTD, behavior, response to KTD, KTD reporting, relationship with the doctors and systems, urgent situations and variations in clinical behavior ${ }^{13}$.

The implementation of the risk for falls management program for the patients is an attempt made to prevent or treat patients with risk for falls as well as those who experience falling incident in the hospital. The nurses, as the largest member of health personnel in the hospital (40$60 \%$ ), and the nursing services provided, are the integral parts of health services, which play a key role in realizing patient safety ${ }^{14}$.

For example, applying the Standard Operating Procedures of risk for falls management for the patients, screening new patients by using the available screening form. If a patient is found with risk for falls, based on the results of screening, he/she will be marked by a yellowidentification-bracelet, and then the patient will be treated according to his/her illness and risk for falls management according to the standard operating procedures, providing information or education to patients and their family about risk for falls possibility, and proding leaflets concerning the handling of the risk for falls. As for patient monitoring with better or worse changes, the nurses will reassess the risk for falls and will document the results into the patients' medical record.

The screening of risk for falls to the patients using a screening form for those with a risk for falls consists of three ways, they are; Morse Fall Scale for adult patients, Humpty Dumpty for children and a checklist of older age checking. The activities undertaken to anticipate and prevent falls with or without injury need to be assessed at the beginning and periodically reviewed further, including, potential risks associated with drug administration schedules and taking action to reduce all of the identified risks. The assessment of risk for falls for the patients has been able to practice since the patient starts to register, by using a fall scale.

The anticipation in terms of patient factors involves the family or the accompany of the patients in preventing falls, inviting and actively participating, teaching things or actions that can be done to prevent the patients from falling, for example, to not to leave the patient alone, closing the bed safety, and suggesting the family to inform the nurses when they want to leave the patient ${ }^{15}$. According to the Guidelines of Patient Safety Incident Reporting (Insiden Keselamatan Rumah Sakit/IKP), the Hospital Patient Safety Committee of 2015 did not specify any form of punishment or warning for the nurses who find the incident, however, it specified that the report can be made by any of hospital staffs who find the incident firstly and anyone or any of the staffs involved in the incident. There are many methods used for identifying risks, one of those is by developing a reporting system which will invite everyone in the organization to care about the dangers or potential dangers that can occur to the patient. Reporting is also important to be used for monitoring the prevention of errors, so it is expected to encourage further investigation ${ }^{16}$.

\section{CONCLUSION}

Based on the results of the research and discussion, it can be concluded that all of the nurses in the inpatient ward in PKU Muhammadiyah Hospital of Gamping have different level of knowledge. It was due to the of lack of socialization to the inpatient ward nurses. From the review of medical records of the inpatients, it was found that not all medical records were completed in compliance or incompleted. It was due to the lack of discipline of nurses served on the ward. So that, there were still some medical records incompleted or non-compliance. It was also found that there were some differences in the answers to nine interview questions given to informants about the obstacles in the implementation of the guidelines of risk for falls.

\section{REFERENCE}

1. Menteri Kesehatan RI. 2014. Peraturan menteri kesehatan republik indonesia nomor 56 tahun 2014 tentang klasifikasi dan perizinan rumah sakit. Diakses dari

http://manajemenrumahsakit.net/wpcontent/uploads/20 14/12/Permenkes-56-Tahun-2014.pdf.

2. Menteri Kesehatan RI. 2011. Peraturan Menteri Kesehatan Republik Indonesia No. 1691/Menkes/Per/VIII/2011 tentang Keselamatan Pasien. Diakses dari www.depkes.go.id.

3. Joint Commission International. 2011. Standar akreditasi Rumah sakit, Enam sasaran Keselamatan Pasien. Edisi ke-4.

4. Menkes RI. 2008. Keputusan Menteri Kesehatan RI Nomor 129/MENKES/SK/II/2008 tentang Standar Pelayanan Minimal Rumah Sakit. 
5. Kongres PERSI. 2012. Laporan Peta Nasional Insiden Keselamatan Pasien. Jakarta.

6. Komariah. 2012. Metode penelitian. Repository. upi.edu/16549/6/S_1001741_Chapter3.pdf.

7. Data Based PKU Muhammadiyah Gamping, 2014.

8. Pratomo, H., dan Sudarti. 1986. Pedoman Usulan Penelitian Bidang Kesehatan Masyarakat dan Keluarga Berencana. Jakarta: Depdikbud.

9. KKP-RS. 2011. Workshop Keselamatan Pasien dan Manajemen Risiko Klinis di Rumah Sakit. Jakarta: PERSI

10. Wilkinson, J.M. (2005). Buku Saku Diagnosis Keperawatan Dengan Intervensi NIC dan Kriteria Hasil NOC. Alih Bahasa Oleh Widyawati (2007). Edisi 7. Jakarta : Penerbit Buku Kedokteran EGC.

11. Aristo. 2007. Hubungan Tes "Timed Up and Go" Dengan Frekuensi Jatuh Pasien Lanjut Usia. Karya Tulis Ilmiah: Fakultas Kedokteran Universitas Diponegoro Semarang.upi.edu/16549/6/S_1001741_Chapter3.pdf.

12. Oliver D, Daly F, Martin FC, and MC Murdo ME. Risk Factors and Risk Assessment tools falls in Hospital In-Patients: A Systematic Review. Age and Ageing. 2004; 33 (2):122-130.

13. Cahyono, J.B. Suhardjo B. 2012. Membangun Budaya Keselamatan Pasien Dalam Praktek Kedokteran. Yogyakarta: Kanisius.

14. Gillies DA. Nursing management a System Approach. 3rd edition. Philadelphia: WB Saunders; 2007.

15. Sugeng, et al. 2014. Pelaksanaan Program Manajemen Pasien dengan Risiko Jatuh di Rumah Sakit. Jurnal Kedokteran Brawijaya, Vol. 28, Suplemen No. 1, 2014. Program Studi Magister Manajemen Rumah Sakit Fakultas Kedokteran Universitas Brawijaya Malang

16. KKP-RS. 2015. Pedoman Pelaporan Insiden Keselamatan Pasien. Jakarta: Komite Keselamatan Pasien Rumah Sakit. 